\title{
Peran Mediasi Komitmen Organisasi: Kontribusi Karakteristik Individu terhadap Kinerja Pegawai
}

\author{
Ahmad Ahmad ${ }^{1}$, Djabir Hamzah ${ }^{2}$, Siti Haerani ${ }^{2}$, Fauziah Umar ${ }^{2}$ \\ Sekolah Tinggi Ilmu Manajemen Indonesia YAPMI Makassar ${ }^{1}$ \\ Fakultas Ekonomi dan Bisnis, Universitas Hasanuddin Makassar ${ }^{2}$ \\ ahmadmanajemen72@gmail.com
}

\begin{abstract}
This study aims to explore the contribution effect of individual characteristics on organizational commitment and employee performance. The design of this research is a survey method using a questionnaire. The sampling technique was proportional stratified random. The number of respondents was determined as 125 employees through the table krejcie-morgan of 220 State Civil Servants, obtained 140 units of analysis (State Civil Apparatus at the South Sulawesi Provincial Health Office), only in its implementation there were 15 respondents who gave incomplete responses so that overall only 125 respondents used. The quantitative approach is used to test and prove hypotheses through the use of WarpPLS 6.0. The results of this study indicate that individual characteristics have a significant impact on employee commitment and performance, commitment also shows real results on employee performance. The resulting mediation role test shows that organizational commitment is not stated as a mediator because without the support of organizational commitment, in its implementation individual characteristics are also able to provide tangible results in improving performance.
\end{abstract}

Keywords: Individual Characteristics, Organizational Commitment, Performance.

\begin{abstract}
Abstrak
Penelitian ini bertujuan untuk mengeksplorasi kontribusi karakteristik individu pada komitmen dan kinerja pegawai. Desain penelitian ini adalah metode survei dengan menggunakan kuesioner. Teknik penentuan sampel adalah proportional stratified random. Jumlah responden ditetapkan sebanyak 125 pegawai melalui tabel krejcie-morgan dari 220 Aparatur Sipil Negara diperoleh 140 unit analisis (Aparatur Sipil Negara pada Dinas Kesehatan Provinsi Sulawesi Selatan), hanya dalam pelaksanaannya terdapat 15 responden yang memberikan respon secara tidak lengkap sehingga secara keseluruhan hanya 125 responden yang digunakan. Pendekatan kuantitatif digunakan untuk menguji dan membuktikan hipotesis melalui penggunaan WarpPLS 6.0. Hasil penelitian ini menunjukkan bahwa karakteristik individu memberikan dampak yang bermakna pada komitmen dan kinerja pegawai, komitmen juga menunjukkan hasil yang nyata pada kinerja pegawai. Pengujian peran mediasi yang dihasilkan menunjukkan jika komitmen organisasional dinyatakan bukan sebagai pemediasi karena tanpa adanya dukungan komitmen organisasi, dalam pelaksanaannya karakteristik individu juga mampu memberikan hasil yang nyata dalam meningkatkan kinerja.
\end{abstract}

Kata kunci: Karakteristik Individu, Komitmen, Kinerja

Alamat korespondensi :

Jl. Perintis Kemerdekaan, Daya, Kec. Biringkanaya

Kota Makassar, Sulawesi Selatan 90241 


\begin{tabular}{lcl}
\hline Permalink/DOI & $:$ & http://dx.doi.org/10.32503/jmk.v5i2.1000 \\
Cara Mengutip & $:$ & Ahmad., dkk. (2020). Peran Mediasi Komitmen Organisasi: \\
& & Kontribusi Karakteristik Individu terhadap Kinerja Pegawai. \\
& JMK (Jurnal Manajemen dan Kewirausahaan), 5 (3), 254-266 \\
& doi: http://dx.doi.org/10.32503/jmk.v5i3.1153 \\
Sejarah Artikel & $: \begin{array}{l}\text { Artikel diterima 6 Agustus 2020; direvisi 15 Agustus 2020; } \\
\text { disetujui 22 Agustus 2020 }\end{array}$ \\
\hline
\end{tabular}

\section{Pendahuluan}

Kesehatan merupakan upaya untuk memenuhi salah satu hak dasar rakyat, yaitu hak untuk memperoleh pelayanan kesehatan sesuai dengan undang-undang Dasar 1945 Pasal 28 ayat (1) dan Undang-undang Nomor 23 Tahun 1992 tentang Kesehatan. Pembangunan kesehatan harus dipandang sebagai salah satu investasi untuk meningkatkan kualitas sumberdaya manusia, yang diukur dengan Indeks Pembangunan Manusia (IPM).

Mutu pelayanan kesehatan di rumah sakit sangat dipengaruhi oleh kualitas sarana fisik, jenis tenaga yang tersedia, obat dan alat kesehatan serta proses pemberian pelayanan kesehatan. Oleh karena itu peningkatan mutu faktor-faktor tersebut termasuk sumber daya manusia dan profesionalisme diperlukan agar pelayanan kesehatan yang bermutu dan pemerataan pelayanan kesehatan dapat dinikmati oleh seluruh lapisan masyarakat. Salah satu profesionalisme di rumah sakit yang sangat berperan dalam pelayanan kesehatan di rumah sakit adalah tenaga keperawatan (Bustami, 2011;59).

Rumah Sakit Umum Provinsi Sulawesi Selatan secara teknis berada dibawah Dinas Kesehatan Provinsi Sulawesi Selatan, dan secara taktis operasional berada pada tanggung jawab kepada Gubernur. Mengingat bahwa rumah sakit saat ini tidak lagi dikelola dengan manajemen yang sederhana, maka untuk dapat bertahan dan berkembangn dalam lingkungan dengan perubahan yang cepat, paradigm manajemen rumah sakit dewasa ini harus dirubah menjadi lebih efektif, efisien dan mempunyai kemampuan untuk mengakomodir perubahan agar mampu memenuhi kebutuhan masyarakat yang muncul akibat perubahan-perubahan yang ada. Dinas kesehatan provinsi Sulawesi Selatan berfungsi sebagai dinas yang menyelenggarakan Urusan Pemerintahan Bidang Kesehatan yang menjadi kewenangan daerah dan tugas pembantuan yang ditugaskan kepada Pemerintah Daerah. Salah satu tugas yang menjadi tanggung jawab dinas kesehatan adalah mengoordinasikan dan menyelenggarakan monitoring, evaluasi, dan pengawasan penyelenggaraan kebijakan teknis bidang kesehatan masyarakat, pencegahan dan pengendalian penyakit, pelayanan kesehatan,sumber daya kesehatan. Pelaksanaan tanggung jawab tersebut, hanya dapat dilakukan jika seluruh sumber daya manusia 
yang terlibat memiliki komitmen yang tinggi terhadap pekerjaan mereka.

Komitmen pegawai dinas kesehatan provinsi Sulawesi Selatan berada pada level yang tinggi pada sisi informasi kesehatan terbukti dengan diperolehnya penghargaan konsistensi data profil kesehatan Indonesia tahun 2019, diantara 32 provinsi di Indonesia hanya terdapat 3 provinsi yang mendapat penghargaan, yaitu provinsi sulawesi selatan, jawa barat dan jawa tengah. Pencapaian tersebut tidak berbanding lurus dengan tingginya tingkat keluhan dan ketidakpuasan pasien maupun keluarga pasien terkait pelayanan kesehatan yang dilakukan Dinas Kesehatan di sejumlah Rumah Sakit di Sulawesi Selatan, kondisi tersebut menunjukkan lemahnya pengawasan di bidang kesehatan (Dinas Kesehatan Provinsi Sulawesi Selatan, 2020).

Hasil dari pelaksanaan suatu pekerjaan dan ditunjukkan melalui kualitas dan kuantitas pelayanan yang maksimal berdasarkan beban pekerjaan yang menjadi tanggung jawab pegawai merupakan parameter kinerja pegawai kesehatan (Mangkunegara, 2013:67), rendahnya kinerja pegawai pada Dinas Kesehatan Provinsi Sulawesi Selatan di akibatkan karena beberapa faktor, salah satu diantara faktor tersebut ditunjukkan dengan rendahnya komitmen pegawai dalam menjalankan fungsinya, hal ini diperlihatkan dengan perilaku pegawai dalam bekerja, seperti yang terlihata pada pegawai yang sering menunda penyelesaian pekerjaan dan kesadaran pegawai untuk mengeluarkan extra effort demi kemajuan organisasi. Kondisi ini menjadi alasan untuk menganalisis komitmen pegawai yang dilatarbelakangi oleh karakteristik pegawai.

\section{Tinjauan Pustaka}

\section{Karakteristik Individu}

Salah satu determinan utama yang mempengaruhi kinerja adalah karakteristik individu, pemahaman tentang perilaku individu dalam organisasi menjadi sangat berarti bagi kelangsungan hidup organisasi, terutama bila dikaitkan dengan upaya organisasi untuk mengatasi berbagai masalah dalam adaptasi atas berbagai perkembangan dan perubahan eksternal dan integritas terhadap kekuatan internal.

Organisasi sebagai suatu wadah akan memungkinkan masyarakat untuk meraih hasil yang sebelumnya tidak dapat dicapai oleh individu secara sendiri-sendiri untuk memuaskan tujuan pribadinya. Demikian pula sebaliknya organisasi membutuhkan orang-orang untuk melakukan aktivitas organisasi guna mencapai tujuan organisasi. Sehingga dengan demikian antara keduanya akan memiliki hubungan yang saling membutuhkan (Yin, N., 2018).

Individu adalah salah satu dimensi yang amat penting dan merupakan faktor pendukung organisasi. Perilaku organisasi pada hakikatnya adalah hasil-hasil interaksi antara individu dengan organisasinya. 
Dalam suatu organisasi perbedaan individu adalah hal yang biasa. Perbedaan-perbedaan tersebut akan dibawa ke dalam dunia kerja, sehingga dengan adanya perbedaan tersebut menyebabkan perilaku individu berbeda satu sama lainnya, walaupun mereka ditempatkan dalam satu lingkungan kerja yang sama. Perbedaan individu membantu menjelaskan mengapa sebagian orang bersedia menerima perubahan dan sebagian lainnya merasa takut terhadap perubahan. Juga mengapa sebagian pegawai hanya bekerja secara baik pada saat mereka diawasi dengan ketat, sementara yang lainnya justru lebih produktif pada saat tidak diawasi. Semua aktivitas organisasi selalu dipengaruhi oleh perbedaan individu (Thoha, 2012: 61).

Karakteristik merupakan sesuatu yang penting. Memahami karakteristik sangatlah penting baik karakteristik diri sendiri maupun orang lain. Mengenali karakteristik diri itu adalah suatu keharusan untuk mengetahui siapa dan di mana posisi kita dalam pandangan orang lain. Memahami karakteristik orang lain tentu saja sangat berguna untuk menentukan bagaimana sikap kita terhadap orang tersebut (Thoha, 2012: 64).

Organisasi merupakan wadah bagi individu untuk mencapai tujuan, baik yang bersifat pribadi maupun organisasional. Individu dengan karakter tersendiri dan organisasi juga memiliki karakter tertentu yang saling menyesuaikan. Karakteristik individu terdiri dari kemampuan, kebutuhan, kepercayaan, pengalaman, pengharapan. Karakteristik individu dicerminkan melalui karakteristik biografis (usia, pendidikan, jenis kelamin, status perkawinan, jumlah tanggungan dalam keluarga dan masa kerja; karakteristik kemampuan (kemampuan fisik dan mental); kepribadian, dan terakhir adalah karakteristik pembelajaran (Robbins dan Judge, 2011:127).

Riset terdahulu yang menggunakan 39 dosen politeknik dengan pemanfaatan regresi berganda memberikan bukti jika karakteristik individu yang dapat dijelaskan melalui; sikap, minat nilai dan kemampuan yang belum baik dan dimiliki pegawai dalam pelaksanaannya tidak dapat meningkatkan kinerja pegawai yang diukur dengan kuantitas, kualitas kerja, ketepatan waktu, dan efektivitas (Hajati, dkk., 2020).

Temuan tersebut relevan dengan temuan Rahman, dkk., (2020) yang menganalisis 38 pegawai kontrak pada Universitas Lambung Mangkurat melalui penggunaan regresi berganda, bahwa karakteristik individu tidak dapat meningkatkan kinerja pegawai. Bukti tersebut terbantahkan berdasarkan temuan studi lainnya, jika individu yang memiliki dan menampilkan karakteristik yang baik terbukti dalam pelaksanaanya dapat meningkatkan kinerja pegawai (Arifudin dan Rusmana, 2020; Nasution, N., 2020). Konsisten dengan temuan tersebut, Simanjuntak, dkk., (2020) menganalisis 30 pegawai pada kantor Pelayanan Kekayaan 
Negara dan Lelang Kota Pematangsiantar, hasil pengujian regresi membuktikan jika karakteristik individu terbukti dapat meningkatkan kinerja.

Adanya diskursus temuan menjadi alasan peneliti untuk menguji kontribusi karakteristik individu terhadap kinerja pegawai dengan menggunakan komitmen sebagai pemediasi yang berfungsi sebagai penguat dalam menjelaskan fenomena dalam studi ini.

\section{Komitmen organisasional}

Pegawai yang berkomitmen tinggi akan menunjukkan effort yang lebih dalam pencapaian tujuan institusi tempat dimana mereka bekerja (Toban dan Sjahruddin, 2016) sehingga dengan kesungguhan organisasi yang tinggi, pegawai akan lebih termotivasi untuk hadir dalam organisasi dan berusaha mencapai tujuan organisasi

Para sarjana telah mengembangkan tipologi komitmen organisasi (Etzioni, 1961; Staw dan Salancik, 1977 ; dalam Sjahruddin dan Sudiro, 2013) yang memproposisikan komitmen sebagai; pertama komitmen sikap (attitudinal commitment) yang mempertimbangkan kesesuaian antara nilai dan tujuan pribadi dengan nilai dan tujuan organisasi, dan keinginan mereka untuk tetap berada dalam organisasi. Pendekatan sikap ini memandang komitmen organisasi sebagai komitmen afektif (Meyer et $a l,, 2012)$ serta berfokus pada proses bagaimana seseorang berpikir hubungannya dengan organisasi
(Mowday et al., 2013), kedua komitmen tingkah laku (behavioral commitment) yang menekankan pada proses dimana individu mengembangkan komitmen tidak pada organisasi tetapi pada tingkah lakunya terhadap organisasi (Toban dan Sjahruddin, 2016).

Perkembangan terakhir dari komitmen organisasi dikemukakan Meyer \& Allen (1991; dalam Toban dan Sjahruddin, 2016) melalui: komitmen afektif (affective) yang berorientasi pada keinginan (want to), komitmen kontinuans (continuance) dengan bersandar pada kebutuhan (need-to), dan komitmen normatif (normative) yang ditunjukkan melalui kewajiban (ought-to) untuk bertahan pada institusi.

Beberapa temuan terdahulu memberikan bukti jika komitmen organisasional rendah maka berdampak pada rendahnya kinerja yang dihasilkan, seperti pada pengujian yang dilakukan Eliyana, A., dan Ma'arif, S. (2019) yang menganalisis kinerja karyawan PT. Pelabuhan Indonesia III dengan menggunakan partial least square, bahwa komitmen berarah negatif dan tidak signifikan pada kinerja. Bukti tersebut terbantahkan dari studi Loan, (2020) pada 547 karyawan perusahaan di Vietnam dengan menggunakan persamaan regresi, bahwa semakin tinggi komitmen yang diperlihatkan pegawai, maka semakin tinggi kinerja yang mereka hasilkan. Hasil serupa juga ditunjukkan Toban, dan Sjahruddin, (2016) melalui pemanfaatan analisis moment of 
structural, bahwa keseluruhan dimensi komitmen organisasi (affective, normative, continuance) terbukti dapat meningkatkan kinerja 197 pegawai SKPD di Kota Makassar, studi tersebut mendukung temuan Nursyamsi, I. (2012) yang menggunakan 100 dosen Ekonomi Universitas Hasanuddin dengan memanfaatkan analisis jalur dalam menganalisis kontribusi komitmen pada kinerja dosen.

\section{Metodologi Penelitian}

Studi ini menguji peran komitmen organisasi sebagai pemediasi dalam menjelaskan kontribusi karakteristik individu terhadap kinerja pegawai. Penarikan sampel menggunakan tabel krejciemorgan dari 220 Aparatur Sipil Negara diperoleh 140 unit analisis (Aparatur Sipil Negara pada Dinas Kesehatan Provinsi Sulawesi Selatan), hanya dalam pelaksanaannya terdapat 15 responden yang memberikan respon secara tidak lengkap sehingga secara keseluruhan hanya 125 responden yang digunakan. Pendekatan kuantitatif digunakan untuk menguji dan membuktikan hipotesis melalui penggunaan WarpPLS 6.0.

\section{Hasil \& Pembahasan}

\section{Karakteristik Responden}

Responden yang digunakan dalam studi ini karakteristik biografis. Sebagai Aparatur Sipil Negara yang dalam menjelaskan tugas dan kewajibannya dilatarbelakangi oleh akhir, dan masa kerja. Penjelasan pada karakteristik biografis tersebut dapat dijelaskan pada tabel dibawah ini:

Tabel 1. Responden

\begin{tabular}{|c|c|c|}
\hline Karakteristik & $\begin{array}{c}\text { Frekuensi } \\
(n=125)\end{array}$ & Persen \\
\hline \multicolumn{3}{|l|}{ Jenis Kelamin } \\
\hline Pria & 74 & 59,2 \\
\hline Wanita & 51 & 40,8 \\
\hline \multicolumn{3}{|l|}{ Usia } \\
\hline $\begin{array}{l}24-30 \\
\text { Tahun }\end{array}$ & 14 & 11,2 \\
\hline $\begin{array}{l}31-37 \\
\text { Tahun }\end{array}$ & 33 & 26,4 \\
\hline $\begin{array}{l}38-44 \\
\text { Tahun }\end{array}$ & 30 & 24,0 \\
\hline $\begin{array}{l}45-51 \\
\text { Tahun }\end{array}$ & 40 & 32,0 \\
\hline $\begin{array}{l}>51 \\
\text { Tahun }\end{array}$ & 8 & 6,4 \\
\hline \multicolumn{3}{|l|}{ Status Pernikahan } \\
\hline $\begin{array}{l}\text { Belum } \\
\text { Menikah }\end{array}$ & 22 & 17,6 \\
\hline Menikah & 103 & 82,4 \\
\hline \multicolumn{3}{|l|}{ Pendidikan Akhir } \\
\hline SMU & 8 & 6,4 \\
\hline Diploma & 29 & 23,2 \\
\hline Sarjana & 61 & 48,8 \\
\hline Magister & 27 & 21,6 \\
\hline \multicolumn{3}{|l|}{ Masa Kerja } \\
\hline $\begin{array}{l}1-7 \\
\text { Tahun }\end{array}$ & 7 & 5,6 \\
\hline $\begin{array}{l}8-14 \\
\text { Tahun }\end{array}$ & 31 & 24,8 \\
\hline $\begin{array}{l}15-21 \\
\text { Tahun }\end{array}$ & 33 & 26,4 \\
\hline $\begin{array}{l}22-28 \\
\text { Tahun }\end{array}$ & 43 & 34,4 \\
\hline $\begin{array}{l}>29 \\
\text { Tahun }\end{array}$ & 11 & 8,8 \\
\hline
\end{tabular}

Pengelompokan berdasarkan usia didominasi oleh pria sebanyak $59,2 \%$, hal ini menjelaskan jika karakteristik pekerjaan didominasi pada pekerjaan yang relevan dengan kemampuan fisik sehingga pria lebih cenderung memiliki kemampuan tersebut dibandingkan wanita. Pada level usia, responden didominasi dengan usia 45-51 Tahun sebanyak 
$32,0 \%$, hal ini memberikan makna jika pegawai telah memiliki usia yang cenderung sangat matang sehingga dengan usia tersebut mereka diharapkan lebih arif dalam berperilaku serta matang dalam proses pengambilan keputusan.

Pada status pernikahan, responden cenderung telah menikah, yaitu sejumlah 103 pegawai atau $82,4 \%$ kondisi mengakibatkan pegawai memiliki tanggung jawab yang tinggi dalam pekerjaan, kondisi tersebut relevan dengan jenjang pendidikan akhir yaitu Sarjana sejumlah 61 pegawai atau 48,8\%, bahwa mereka dipandang memiliki pengetahuan yang cukup dalam melaksanakan pekerjaannya. Konsisten dengan masa kerja yang didominasi pada masa kerja rentangan 22 - 28 Tahun sejumlah 43 pegawai atau $34,4 \%$

\section{Kesahihan model penelitian}

Kelayakan model dalam WarpPLS dapat ditentukan melalui tiga komponen pengukur, yaitu; APC, ARS, dan AARS (Kock, N., 2011). Untuk itu hasilnya disajikan sebagai berikut:

\section{Tabel 2. Model fit and quality indices}

\begin{tabular}{ll}
\hline \multicolumn{1}{c}{ Measurement } & $p$-value \\
\hline Average path coefficient & $=0.572$, \\
(APC) & $\mathrm{P}<0.001$ \\
Average $R$-squared & $=0.695$, \\
(ARS) & $\mathrm{P}<0.001$ \\
Average adjusted $R$ - & $=0.692$, \\
squared $(A A R S)$ & $\mathrm{P}<0.001$ \\
\hline
\end{tabular}

Ketiga pengukur dinyatakan memenuhi persyaratan pemodelan, karena memberikan nilai rata-rata >
0.05 dan probability value $=<0.05$

\section{Keabsahan konstruk}

Validitas konstruk pada pengujian combined loading and cross-loadings menjelaskan jika nilai konstruk >0.60 maka konstruk tersebut dinyatakan memenuhi.

Tabel 3. Combined loadings and crossloadings *

\begin{tabular}{ccccc}
\hline $\begin{array}{c}\text { Construc } \\
t\end{array}$ & KI & KP & KO & $\begin{array}{c}p- \\
\text { value }\end{array}$ \\
\hline & 0.94 & & & $<0.00$ \\
KMP & 4 & - & - & 1 \\
& 0.83 & & & $<0.00$ \\
KBT & 9 & - & - & 1 \\
& 0.91 & & & $<0.00$ \\
KPC & 9 & - & - & 1 \\
& 0.93 & & & $<0.00$ \\
PGL & 8 & - & - & 1 \\
& 0.72 & & & $<0.00$ \\
PHP & 0 & - & - & 1 \\
& & 0.90 & & $<0.00$ \\
QTY & - & 2 & - & 1 \\
& & 0.91 & & $<0.00$ \\
QLT & - & 9 & - & 1 \\
& & 0.95 & & $<0.00$ \\
TME & - & 8 & - & 1 \\
& & 0.95 & & $<0.00$ \\
EFE & - & 7 & - & 1 \\
& & & 0.89 & $<0.00$ \\
AC & - & - & 3 & 1 \\
& & & 0.91 & $<0.00$ \\
CC & - & - & 2 & 1 \\
& & & 0.90 & $<0.00$ \\
NC & - & - & 0 & 1 \\
\hline
\end{tabular}

Hasil pengujian menunjukkan jika keseluruhan konstruk memiliki nilai $>0.60$ dengan probability value $<0.05$ sehingga validitas konstruk reflektif dinyatakan terpenuhi.

\section{Korelasi antar variabel}

Korelasi antar variabel bertujuan untuk mengidentifikasi pemodelan apakah terdapat keeratan hubungan antar variabel analisis, semakin besar nilai korelasi, maka semakin 
membuktikan jika pemodelan dan kausalitas yang akan diuji semakin baik (Ghozali dan Latan, 2014).

Tabel 4. Correlations among l.vs. with sq. rts. of AVEs

\begin{tabular}{|c|c|c|c|c|}
\hline Measure & & $\mathrm{KI}$ & KP & $\mathrm{KO}$ \\
\hline \multirow{4}{*}{$\begin{array}{c}\text { Correlatio } \\
n s\end{array}$} & KI & 0.876 & 0.826 & 0.757 \\
\hline & K & & & 0821 \\
\hline & $\mathrm{r}$ & $0.8<0$ & 0.934 & 0.831 \\
\hline & $\mathrm{O}$ & 0.757 & 0.831 & 0.902 \\
\hline \multirow{6}{*}{ p-values } & & & $<0.00$ & $<0.00$ \\
\hline & KI & 1.000 & 1 & 1 \\
\hline & $\mathrm{K}$ & $<0.00$ & & $<0.00$ \\
\hline & $\mathrm{P}$ & 1 & 1.000 & 1 \\
\hline & $\mathrm{K}$ & $<0.00$ & $<0.00$ & \\
\hline & $\mathrm{O}$ & 1 & 1 & 1.000 \\
\hline
\end{tabular}

Nilai korelasi pada ketiga variabel keseluruhan berada pada > 0,60 dengan $\mathrm{p}$-value $<0.05$, sehingga dapat dinyatakan jika masing-masing variabel memiliki keeratan hubungan yang kuat dan nyata.

\section{Kehandalan Konstruk}

Keandalan konstruk dari variabel analis ditunjukkan pada nilai Cronbach Alpha, jika Cronbach Alpha $>0,60$ maka konstruk yang digunakan dipandang handal dalam menjelaskan variabel pengamatan.

\section{Tabel 5. Latent variable coefficient}

\begin{tabular}{lccc}
\hline \multicolumn{1}{c}{ Measure } & KI & KP & KO \\
\hline R-squared & - & 0.780 & 0.611 \\
Adj. -squared & - & 0.776 & 0.608 \\
$\begin{array}{l}\text { Composite } \\
\text { Reliability }\end{array}$ & 0.942 & 0.965 & 0.929 \\
Cronbach Alpha & 0.922 & 0.951 & 0.885 \\
Avg.Var. Extract & 0.768 & 0.873 & 0.813 \\
Full Collin VIF & 3.308 & 4.578 & 3.410 \\
Q-Squared & - & 0.779 & 0.609 \\
\hline
\end{tabular}

Nilai $R$-squared $\mathrm{KI} \rightarrow \mathrm{KP}=$ 0,78 dan $\mathrm{KI} \rightarrow \mathrm{KO}=0,611$, sementara nilai $Q$-squared untuk $\mathrm{KI} \rightarrow \mathrm{KP}=0,779$ dan $\mathrm{KI} \rightarrow \mathrm{KO}=0,609$ berdasarkan hasil tersebut, maka dapat dijelaskan jika pemodelan mediasi dalam studi ini lebih rendah kontribusinya dibandingkan direct effect. Pada kehandalan konstruk ditemukan jika keseluruhan nilai composite reliability dan cronbach alpha >0.60 (Ghozali dan Latan, 2014). Sehingga dapat dinyatakan jika dengan kehandalan tersebut, menjadi pemicu tingginya kontribusi dari masing-masing kausalitas pemodelan.

\section{Kontribusi Langsung}

Pada pengujian WarpPLS untuk hipotesis langsung ditunjukkan dengan pemodelan dan tabel, untuk itu dapat ditunjukkan sebagai berikut:

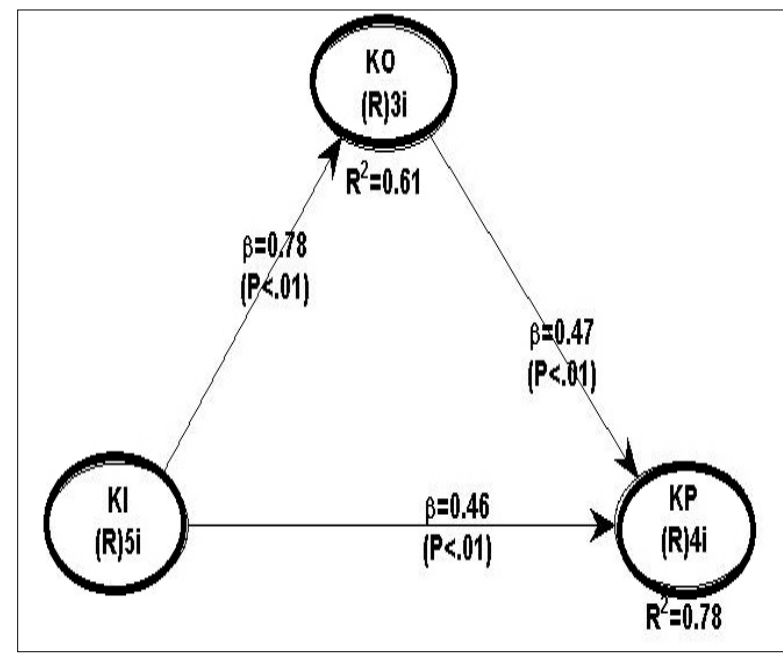

\section{Gambar 1. Model Struktural}

Gambar tersebut menjelaskan jika seluruh kausalitas langsung yang diuji memberikan efek bermakna dan nyata dalam meningkatkan kinerja pegawai 
Tabel 6. Hipotesis langsung

\begin{tabular}{|c|c|c|c|c|}
\hline \multicolumn{2}{|c|}{ Measure } & $\mathrm{KI}$ & $\mathrm{KP}$ & $\mathrm{KO}$ \\
\hline \multirow{3}{*}{$\begin{array}{l}\text { Path } \\
\text { coefficients }\end{array}$} & KP & 0.463 & - & 0.470 \\
\hline & $\mathrm{KO}$ & 0.782 & - & - \\
\hline & $\mathrm{KP}$ & $<0.001$ & - & $<0.001$ \\
\hline$p$-values & $\mathrm{KO}$ & $<0.001$ & - & - \\
\hline \multirow{2}{*}{$\begin{array}{l}\text { Standard } \\
\text { errors }\end{array}$} & $\mathrm{KP}$ & 0.080 & & 0.080 \\
\hline & $\mathrm{KO}$ & 0.074 & & \\
\hline \multirow{2}{*}{$\begin{array}{l}\text { Effect } \\
\text { sizes }\end{array}$} & $\mathrm{KP}$ & 0.386 & & 0.393 \\
\hline & $\mathrm{KO}$ & 0.611 & & \\
\hline
\end{tabular}

Hasil pengujian memberikan bukti jika $\mathrm{KI} \rightarrow \mathrm{KP}$ dengan nilai koefisien jalur $=0,463$ dan $\mathrm{p}$-value $<0.001=<0,05$, KI $\rightarrow \mathrm{KO}$ nilai koefisien jalur $=0,782$ dan $\mathrm{p}$-value $<0.001=<0,05$, serta $\mathrm{KO} \rightarrow \mathrm{KP} 0,470$ dengan p-value $<0.001=<0,05$. Efek size terbesar diperoleh dari $\mathrm{KI} \rightarrow \mathrm{KO}$ $=0,611$ atau sebesar $61,1 \%$.

Tabel 7. Hipotesis tidak langsung

\begin{tabular}{lcccc}
\hline $\begin{array}{l}\text { Measureme } \\
n t\end{array}$ & & \multicolumn{3}{c}{$\mathrm{K}$} \\
$\begin{array}{l}\text { P values for } \\
\text { indirect } \\
\text { effects }\end{array}$ & $\mathrm{KP}$ & \multicolumn{3}{c}{$<0.001$} \\
& $\mathrm{KP}$ & 0.830 & - & 0.470 \\
Total effects & $\mathrm{K}$ & 0.782 & - & - \\
& $\mathrm{O}$ & $<0.00$ & & $<0.00$ \\
& $\mathrm{KP}$ & 1 & - & 1 \\
$\begin{array}{l}P \text { values for } \\
\text { total effects }\end{array}$ & $\mathrm{K}$ & $<0.00$ & - & - \\
Standard & $\mathrm{O}$ & 1 & & \\
errors for & $\mathrm{K}$ & 0.073 & - & 0.080 \\
total effects & $\mathrm{O}$ & 0.074 & - & - \\
\hline
\end{tabular}

Pengujian indirect effect menunjukkan hasil jika $\mathrm{KI} \rightarrow \mathrm{KO}$ $\rightarrow \mathrm{KP}=<0.001=<0,05$, hasil tersebut menjelaskan jika peran komitmen organisasi sebagai pemediasi terbukti dalam menganalisis pengaruh karakteristik individu terhadap kinerja pegawai.

\section{Rasionalisasi Hasil}

Kontribusi karakteristik individu pada komitmen organisasional

Pegawai dalam suatu organisasi mempunyai pandangan, tujuan, kebutuhan dan kemampuan yang berbeda satu sama lain, perbedaan tersebut berdampak pada komitmen mereka terhadap tempat mereka bekerja. Pegawai yang memiliki karakteristik yang baik (positif) senantiasa menginginkan tempat kerja mereka dapat maju dan berkembang. Pernyataan tersebut menjelaskan jika karakteristik individu merupakan determinan dari komitmen organisasional.

Studi ini mengkonfirmasikan bahwa semakin baik karakteristik yang dimiliki individu maka semakin tinggi kinerja yang dihasilkan. Pernyataan tersebut menjelaskan bahwa pengharapan pegawai yang tinggi berdampak nyata pada keinginan untuk senantiasa bertahan dan memajukan organisasi. Temuan dari penelitian ini mendukung hasil sebelumnya bahwa karakteristik individu berdampak nyata pada tingginya komitmen yang dihasilkan (Lumbanraja, P., 2009; Emiyanti, dkk., 2020).

\section{Kontribusi karakteristik individu pada Kinerja pegawai}

Pegawai yang dalam pelaksanaannya memiliki perilaku atau karakter yang positif maupun negatif berdampak pada pencapaian kinerja yang mereka realisasikan. Karakter individu yang baik cenderung mengikuti aturan atau 
ketentuan yang berlaku dalam pekerjaan sehingga dengan kemampuan tersebut berdampak pada hasil kerja yang dicapai. Hasil penelitian ini mengkonfirmasikan jika karakter individu yang baik terbukti berdampak pada penciptaan kinerja pegawai yang tinggi. Kebermaknaan tersebut diakibatkan karena dalam keseharian pegawai memiliki kepercayaan yang kuat terhadap kemampuan mereka dalam menyelesaikan segala pekerjaan yang menjadi tanggung jawabnya sehingga berdampak pada kuantitas pekerjaan yang dihasilkan semakin meningkat. Hasil studi ini membantah temuan beberapa peneliti, jika karakteristik individu dalam pelaksanaannya tidak dapat meningkatkan kinerja pegawai (Hajati, dkk., 2020; Rahman, dkk., 2020). Studi ini mendukung temuan peneliti lainnya, jika individu yang memiliki dan menampilkan karakteristik yang baik terbukti dalam pelaksanaanya dapat meningkatkan kinerja pegawai BRI (Arifudin dan Rusmana, 2020; Nasution, N., 2020; Simanjuntak, dkk., 2020).

\section{Kontribusi organisasional pada Kinerja pegawai}

Jika kontribusi pegawai dalam bekerja ditentukan oleh diri pegawai, maka berdampak pada keinginan untuk meningkatkan afektif pegawai pada organisasi. Pegawai dengan komitmen afektif yang tinggi memiliki motivasi kerja yang tinggi sehingga mereka akan memberikan hasil yang terbaik pada organisasi.

\begin{abstract}
Semakin tinggi komitmen pegawai terhadap organisasi mengakibatkan semakin meningkatkan keinginan pegawai untuk melindungi dan memberikan segala kemampuan yang dimilikinya untuk menghasilkan pekerjaan yang berkualitas, termasuk mencurahkan pikirannya untuk kepentingan organisasi Komitmen organisasional mendorong pegawai untuk mempertahankan pekerjaannya dan menunjukkan hasil yang seharusnya. Pernyataan tersebut menjelaskan jika komitmen pegawai berada pada level yang tinggi sehingga berdampak nyata terhadap tingginya kinerja yang mereka hasilkan. Hasil ini membantah temuan Eliyana dan Ma'arif, S. (2019) bahwa komitmen berdampak negatif tidak signifikan pada kinerja. Selain itu riset ini relevan dengan temuan Loan, L. (2020), jika komitmen yang tinggi dan ditunjukkan karyawan terbukti meningkatkan kinerja mereka (Nursyamsi, 2012; Toban dan Sjahruddin, 2016; Emiyanti, dkk., 2020).
\end{abstract}

Kontribusi karakteristik individu pada Kinerja pegawai dimediasi komitmen organisasional

Pegawai yang bekerja untuk jangka waktu yang lama, memiliki hubungan erat dan ikatan yang kuat dengan organisasi. Karakteristik individu yang ditampilkan melalui kepercayaan diri yang tinggi dan kemampuan diri yang tinggi mengakibatkan mereka lebih berorientasi pada kinerja yang dihasilkan, kondisi tersebut terlihat 
dari perasaan dan perilaku positif mereka terhadap organisasi. Apabila lama bekerja berdasarkan pilihan positif, maka hal ini akan meningkatkan ikatan afektif karyawan dengan organisasi. Karyawan tersebut memiliki perasaan emosional dan keyakinan akan nilai-nilai organisasinya yang kuat sehingga menyebabkan kemampuan mereka untuk memunculkan pekerjaan yang berkualitas. Hubungan antara keyakinan dan sikap atas hasil jauh lebih kuat sehingga komitmen dapat memberikan dampak nyata dalam menjelaskan pengaruh karakteristik individu pada kinerja pegawai, walaupun dalam pemodelan peran mediasi yang dihasilkan dinyatakan bukan sebagai pemediasi karena tanpa adanya dukungan komitmen organisasi, dalam pelaksanaannya karakteristik individu juga mampu memberikan hasil yang nyata dalam meningkatkan kinerja.

\section{Simpulan}

Karakteristik yang baik dan dimiliki individu berdampak nyata pada tingginya kinerja yang dihasilkan, pengharapan pegawai pada dirinya dan organisasi mengakibatkan tingginya keinginan pegawai untuk senantiasa bertahan dan memajukan organisasi.

Karakteristik individu yang dimiliki pegawai senantiasa mengikuti aturan atau ketentuan pada pekerjaan, sehingga melalui kondisi tersebut dapat menstimulasi hasil kerja yang dicapai. Individu dengan karakter yang baik terbukti mampu menghasilkan kinerja pegawai sesuai dengan harapan organisasi. Hal ini disebabkan, kepercayaan pegawai yang tinggi dan dukungan kemampuan kerja mengakibatkan tingginya kuantitas penyelesaian pekerjaan.

Keinginan karyawan untuk memberikan perhatian penuh dengan segala kemampuan mereka menjadi pemicu dalam menghasilkan pekerjaan yang berkualitas. Komitmen pegawai yang tinggi mendorong karyawan untuk loyal pada pekerjaannya bahwa komitmen pegawai berada pada level yang tinggi sehingga terbukti dapat meningkat kinerja pegawai.

Keyakinan dan sikap pada hasil pekerjaan yang kuat memberikan kontribusi positif dalam menganalisis pengaruh karakteristik individu pada kinerja pegawai, namun hasil tersebut tidak mampu menjelaskan arti pentingnya komitmen sebagai kausalitas tidak langsung sehingga dapat dijelaskan jika komitmen dalam studi ini dinyatakan bukan sebagai pemediasi karena walaupun tidak memperoleh kontribusi positif dari komitmen organisasi, karakteristik individu terbukti secara langsung dapat menghasilkan kinerja pegawai yang berada pada performa tinggi.

Limitasi dari studi ini terletak pada tidak digunakannya determinan lainnya sebagai pembentuk kinerja, di sisi lain juga ditemukan adanya ketidaksinkronan regulasi pemerintah dengan pelaksanaannya utamanya pada pegawai level atas sehingga membatasi eksplorasi studi ini lebih 
jauh, untuk itu diharapkan pentingnya pengawasan pemerintah dalam menjamin pelaksanaan regulasi yang ada.

\section{Daftar Pustaka}

Arifudin, O., dan Rusmana, F. D. (2020). Pengaruh Lingkungan Kerja Dan Karakteristik Individu Terhadap Kinerja Pegawai Bank BRI Syariah Kabupaten Subang. Islamic Banking: Jurnal Pemikiran Dan Pengembangan Perbankan Syariah, 6(1), 35-46

Bustami, M. (2011). Penjaminan Mutu Pelayanan Kesehatan dan Akseptabilitasnya. Jakarta: Erlangga.

Dinas Kesehatan Provinsi Sulawesi Selatan. (2020). Penghargaan Kesehatan dan Kualitas Pengawasan Kesehatan di Sulawesi Selatan. Makassar

Eliyana, A., dan Ma'arif, S. (2019). Job satisfaction and organizational commitment effect in the transformational leadership towards employee performance. European Research on Management and Business Economics, 25(3), 144-150.

Emiyanti, L., Rochaida, E., dan Tricahyadinata, I. (2020). Pengaruh Karakteristik Individu Dan Motivasi Intrinsik Terhadap Komitmen Afektif Dan Kinerja Pegawai. The Manager Review, 2(1). 15-24

Ghozali, I., dan Latan, H. (2014). Partial least square concepts, methods and applications using the WarpPLS 5.0 program. Universitas Diponegoro, Semarang.

Nawawi, H. (2018). Manajemen Sumber Daya Manusia Untuk Bisnis Yang Kompetitif. Yogyakarta. Gadjah Mada Pers.

Hajati, D. I., Artiningsih, D. W., dan Wahyuni, N. (2020). Pengaruh
Karakteristik Individu, Karakteristik Pekerjaan dan Karakteristik Organisasi terhadap Kinerja Pegawai (Studi pada Politeknik Kotabaru). Jurnal Bisnis dan Pembangunan, 7(1), 1-10.

Kock, N. (2011). Using WarpPLS in ecollaboration studies: Descriptive statistics, settings, and key analysis results. International Journal of e-Collaboration (IJeC), 7(2), 1-18.

Loan, L. (2020). The influence of organizational commitment on employees' job performance: The mediating role of job satisfaction. Management Science Letters, 10(14), 3307-3312.

Lumbanraja, P. (2009). Pengaruh Karakteristik Individu, Gaya Kepemimpinan dan Budaya Organisasi Terhadap Kepuasan Kerja dan Komitmen Organisasi (Studi Pada Pemerintah Daerah Di Provinsi Sumatera Utara). Jurnal Aplikasi Manajemen, 7(2), 450-468.

Mangkunegara, A. P. (2013). Manajemen Sumber Daya Manusia: Cetakan Kesebelas. Bandung: PT. Remaja Rosdakarya.

Meyer, J. P., Stanley, L. J., dan Parfyonova, N. M. (2012). Employee commitment in context: The nature and implication of commitment profiles. Journal of Vocational Behavior, 80(1), 1-16

Mowday, R. T., Porter, L. W., dan Steers, R. M. (2013). Employeeorganization linkages: The psychology of commitment, absenteeism, and turnover. Academic press.

Nasution, N. (2020). Pengaruh Job Insecurity, Fasilitas Kerja Dan Karakteristik Individu Terhadap Prestasi Kinerja Pegawai Puskesmas Bromo Medan. Tijarah: Jurnal Ekonomi dan Bisnis, 2(20). 
Nursyamsi, I. (2012). Pengaruh Kepemimpinan, Pemberdayaan, dan Stres Kerja terhadap Komitmen Organisasional serta dampaknya terhadap kinerja dosen. In Conference In Business, Accounting, And Management (CBAM) 1, (2), 405-423.

Pemerintah Republik Indonesia. (1992). Undang Undang No. 23 Tahun 1992 Tentang: Kesehatan.

Rahman, F., Rahmawati, E., dan Utomo, S. (2020). Pengaruh Karakteristik Individu, Karakteristik Pekerjaan, Dan Karakteristik Organisasi Terhadap Kinerja Pegawai Kontrak (Studi Pada FISIP ULM Banjarmasin). Jurnal Bisnis dan Pembangunan, 9(1), 69-82

Robbins, S. dan Judge, T.A. (2011) Organizational Behavior (Perilaku Organisasi). Jakarta: Salemba Empat.

Simanjuntak, D. A., Siregar, R. T., Sisca, S., dan Chandra, E. (2020). Pengaruh OCB (Organizational Citizenship Behavior) dan Karakteristik Individu terhadap Kinerja Pegawai pada Kantor Pelayanan Kekayaan Negara dan Lelang Kota Pematangsiantar. Maker: Jurnal Manajemen, 6(1), 72-86.

Sjahruddin, H., dan Sudiro, A. A. (2013). Organizational justice, organizational commitment and trust in manager as predictor of organizational citizenship behavior. Interdiciplinary $J$. of contemporary Res. Bus.(IJCRB), 4(12), 133-141.

Thoha, Miftah. (2012). Prilaku Organisasi Konsep Dasar dan Implikasinya. Jakarta : Rajawali Pers

Toban, C., dan Sjahruddin, H. (2016). The antecedent and consequence of Organizational Commitment and Job Satisfaction. Journal of Business and Management Sciences, 4(2), 26-33.

Yin, N. (2018). The influencing outcomes of job engagement: an interpretation from the social exchange theory. International

Journal of Productivity and Performance Management. 